\title{
Pengembangan kawasan agropolitan Bromo Tengger Semeru
}

\section{Agropolitan area development Bromo Tengger Semeru}

\author{
Karnaji \\ Departemen Sosiologi, Fakultas Ilmu Sosial dan Ilmu Politik, Universitas Airlangga \\ E-mail: karnaji@fisip.unair.ac.id
}

\begin{abstract}
Abstrak
Kesadaran dan komitmen Pemerintah Daerah Provinsi Jawa Timur untuk menjaga kelestarian lingkungan hidup bukan saja makin meningkat, tetapi juga makin sistematis dan implementatif. Di atas kertas telah dirumuskan kebijakan dan skenario pengembangan kawasan agropolitan Bromo Tengger Semeru. Tetapi, dalam kenyataan upaya untuk mengembangkan komoditi unggulan dan memanfaatkan kawasan tersebut ternyata bukanlah hal yang mudah. Ada berbagai persoalan yang timbul, bukan hanya berkaitan dengan ancaman perubahan perunutkan lahan, tetapi ditengarai juga kurangnya dukungan berbagai infrastruktur yang dibutuhkan. Kegiatan bertujuan untuk mengkaji situasi problematik yang timbul dalam upaya pengembangan kawasan agropolitan Bromo Tengger Semeru sekaligus mengkaji pengaruh kebijakan dan program pembangunan serta merumuskan rekomendasi untuk meningkatkan efektivitas kebijakan yang mendukung implementasi pembangunan yang berkelanjutan di kawasan agropolitan Bromo Tengger Semeru. Metodenya yaitu pra-lapangan, pelingkupan, baseline data, analisis, pengkajian, perumusan kebijakan program dan yang terakhir perbaikan. Berbagai permasalahan agrobisnis telah ditemukan mulai dari kurangnya sarana prasarana sampai dengan tidak mampu bersaing di pasaran. Ada pula berbagai rekomendasi berbagai program utama yang telah ditemukan. Oleh karena itu harus di terapkan beberapa program utama untuk keberhasilan pengembanagn kawasan agropolitan Bromo Teengger Semeru.
\end{abstract}

Kata kunci: kesadaran; kebijakan; problematik; agrobisnis; program.

\begin{abstract}
The awareness and commitment of the Regional Government of the Province of East Java to preserve the environment is not only increasing, but also more systematic and implementation. On paper, policies and scenarios for the development of the Bromo Tengger Semeru agropolitan area have been formulated. However, in reality the effort to develop superior commodities and utilize the region was apparently not an easy thing. In the field, there are various problems that arise, not only related to the threat of land acquisition change, but also the lack of support for various infrastructure needed. The activity aims to study the problematic situations arising in the efforts to develop the Bromo Tengger Semeru agropolitan area while also examining the effects of development policies and programs and formulate recommendations to improve the effectiveness of policies that support the implementation of sustainable development in the Bromo Tengger Semeru agropolitan area. The methods are pre-field, scoping, baseline data, analysis, assessment, program policy formulation and the last is improvement. Various agribusiness problems have been found ranging from lack of infrastructure to being unable to compete in the market. There are also various recommendations for various main programs that have been found. Therefore, several major programs must be implemented for the successful development of the Bromo Teengger Semeru agropolitan area.
\end{abstract}

Keywords: awareness; policy; problematic; agribusiness; program

\section{Pendahuluan}

Pada umumnya pengembangan wilayah mengacu pada produktivitas wilayah yang berubah. Pengembangan wilayah dapat diukur dari kesempatan kerja, peningkatan populasi penduduk, tingkat pendapatan, dan nilai tambah industri pengolahan. Pengembangan wilayah merupakan strategi memanfaatkan dan mengkombinasikan faktor internal dan eksternal sebagai peluang dan potensi sehingga dapat digunakan untuk meningkatkan produksi wilayah akan barang dan jasa. (Friedman \& Allonso, 1978) 
Terdapat dua tujuan pengembangan wilayah yaitu dari segi sosial dan ekonomis. Hal ini berarti, pengembangan wilayah adalah sebuah upaya untuk memberikan kesejahteraan dan meningkatkan kualitas hidup masyarakat, sehingga menciptakan pusat-pusat produksi, memberikan kemudahan prasarana dan pelayanan logistik , dsb. (Tri Utomo,1999).

Pengembangan Wilayah dari Bawah (Development From Below) berada pada kendali lembagalembaganya sendiri guna menciptakan arah pengebangan tujuan wilayah itu sendiri. Konsep ini berbeda dengan konsep pengembangan dari atas dalam tingkat integrasi yang diinginkan antar wilayah maju dan kurang maju. Selain itu, kapasitas dari wilayah tertentu untuk menentukan kebijakan pada prosesnya melibatkan masyarakat. Kemudian pengembangan wilayah dari atas atau Sistem Bottom Up Sistem pengembangan wilayah di Indonesia sebelum adanya otonomi daerah dilaksanakan secara top down, baik kebijakan perluasan wilayah administratif maupun pembentukan wilayah kawasan ekonomi. Hal yang sama juga dilakukan dalam pembentukan kawasan khusus yang mengutamakan landasan kepentingan nasional dengan mencerminkan karakteristik pendekatan regionalisasi sentralistik. Hal ini aspek pengambilan keputusan dilaksanankan secara top down. (Soejono, 2005).

Keberadaan Taman Nasional Bromo Tengger Semeru sangat penting untuk melestarikan flora dan fauna dan untuk menjaga ekosistem yang ada. Selain itu, keberadaan Taman Nasional Bromo Tengger Semeru juga memiliki peran penting guna sebagai menunjang kegiatan penelitian, pendidikan, rekreasi dan budidaya. Taman Nasional Bromo Tengger Semeru menjadi Taman Nasional pada tanggal 14 Oktober 1982. Menurut surat pernyataan Menteri Agraria Nomor 736 / X / 1982, dengan daerah yang luas 50.000 Ha yang menjadi Taman Nasional. Kemudian pada tanggal 23Mei, 1997 Menteri Agraria mengeluarkan Surat Keputusan Nomor: 278 / KptsVI / 1997 tentang menandakan penunjukan daerah luas 50.276,20 Ha sebagai Taman Nasional Bromo Tengger Semeru (East Java Departement of Tourism, art and Culture Service, 2000).

Peran wilayah perdesaan juga penting dalam menjamin perekonomian nasional terutama dilihat dalam pendekatan "rural-based national development". Potensi dan sumberdaya alam di wilayah perdesaan menyediakan berbagai macam bentuk barang dan jasa yang dibutuhkan, terutama adanya: (1) ketersediaan pangan penduduk di wilayah perdesaan maupun di wilayah perkotaan, (2) ketersediaan tenaga kerja pembangunan, terutama di wilayah perkotaan, (3) ketersediaan bahan baku untuk industry, serta (4) adanya komoditi untuk diekspor ke luar negeri. (Sitorus, 2010)

Teori Agropolitan, lebih memilih pendekatan kebutuhan dasar dan lebih fokus pada pengembangan daerah pedesaan melalui konsep proyek pertanian. (Friedmann \& Alonso 1975) Proyek pertanian didasarkan pada ekonomi pertanian yang tumbuh dan berkembang dengan menjalankan sistem dan usaha agribisnis yang dapat melayani dan mendorong kegiatan pengembangan usaha pertanian (agribisnis) di wilayah sekitarnya (Suyanto, 2005; Suyanto, 2008). Selain itu, kondisi pembangunan yang timpang memiliki sifat interregional sehingga mengakibatkan timbulnya gejala urban bias (Michael, 1977; Rustiadi, 2007; Sitorus, 2010).

Kesadaran dan komitmen Pemerintah Daerah Provinsi Jawa Timur untuk menjaga kelestarian lingkungan hidup bukan saja makin meningkat, tetapi juga makin sistematis dan implementatif. Peningkatan kondisi kesejahteraan masyarakat, akselerasi pembangunan di bidang perekonomian dan kegiatan pembangunan yang berwawasan lingkungan adalah tiga hal yang dicoba dikembangkan Pemerintah Provinsi Jawa Timur bersejajaran dalam konsep pembangunan yang berkelanjutan. 
Telah disadari bahwa pembangunan yang menafikan arti penting kelestarian lingkungan akan beresiko melahirkan hal-hal yang kontra-produktif dan merugikan masyarakat dalam jangka menengah mau pun jangka panjang. Dalam RPJMD Provinsi Jawa Timur telah ditegaskan bahwa pembangunan berkelanjutan adalah sebuah konsep dan strategi pembangunan yang menjadi acuan kebijakan dan pelaksanaan berbagai program di Provinsi Jawa Timur saat ini, dan di masa depan. Pembangunan berkelanjutan di sini dipahami Pemerintah Provinsi Jawa Timur sebagai proses transformasi progresif terhadap struktur sosial, ekonomi dan politik untuk meningkatkan kepastian masyarakat dalam memenuhi kepentingannya saat ini tanpa mengorbankan hak dan kemampuan generasi mendatang dalam memenuhi kepentingan mereka.

Pembangunan berkelanjutan secara konseptual mengandung dua dimensi, yaitu; pertama, dimensi waktu karena dalam prosesnya memastikan adanya berkelanjutan pembangunan dan kondisi sumber daya yang tak terputus dan kedua dimensi interaksi antara sistem ekonomi, sistem sumber daya alam dan lingkungan yang saling berkaitan dan mendukung. Sebuah daerah yang berkomitmen melaksanakan program pembangunan yang berkelanjutan, bukan saja akan dapat memastikan terpeliharanya sumber daya alam yang stabil, dan menghindari eksploitasi sumber daya, tetapi lebih jauh juga akan memperhatikan kelangsungan dan keberlanjutan sistem ekologi.

Dalam rangka memastikan agar pembangunan yang dijalankan benar-benar memperhatikan aspek kelestarian lingkungan dan berkelanjutan, salah satu langkah yang perlu dilakukan Pemerintah Provinsi Jawa Timur adalah menyusun Kajian Lingkungan Hidup Strategis (KLHS). Dalam Undang Undang Republik Indonesia Nomor 32 Tahun 2009 tentang Perlindungan dan Pengelolaan Lingkungan Hidup dijelaskan bahwa yang dimaksud dengan Kajian Lingkungan Hidup Strategis (KLHS) pada dasarnya adalah rangkaian analisis yang sistematis, menyeluruh dan partisipatif untuk memastikan bahwa prinsip pembangunan berkelanjutan telah menjadi dasar dan terintegrasi dalam pembangunan suatu wilayah dan/atau kebijakan, rencana, dan/atau program.

KLHS adalah salah satu instrumen yang dibutuhkan untuk upaya pencegahan pencemaran dan/atau kerusakan lingkungan hidup, selain instrumen lain seperti kebijakan tata ruang, baku mutu lingkungan hidup, kriteria baku kerusakan lingkungan hidup, Analisis Mengenai Dampak Lingkungan Hidup (AMDAL), dan berbagai instrumen lainnya yang concern pada kelestarian lingkungan. Sesuai ketentuan yang berlaku, pemerintah dan pemerintah daerah wajib membuat KLHS untuk memastikan bahwa prinsip pembangunan berkelanjutan telah menjadi dasar dari kebijakan ddan program pembangunan yang dikembangkan di suatu wilayah, terutama kebijakan dan program yang berpotensi menimbulkan dampak dan/atau resiko kerusakan lingkungan. Hal-hal yang beresiko menimbulkan ancaman bagi kelestarian lingkungan, seperti kemerosotan keanekaragaman hayati, penurunan mutu dan kelimpahan sumber daya alam, peningkatan alih fungsi kawasan hutan/lahan, resiko terjadinya bencana, penigkatan jumlah penduduk miskin, resiko terhadap kesehatan manusia, dan lain-lain, adalah hal-hal yang perlu diantisipasi dan dicegah melalui KHLS agar pemerintah dan pemerintah daerah tidak terjerumus dalam kebijakan dan program pembangunan yang kontra-produktif bagi kelestarian lingkungan.

Dalam RPJMD Provinsi Jawa Timur, telah diidentifikasi beberapa isu strategis yang berkaitan dengan kelestarian lingkungan. Beberapa isu strategis yang terkait dengan KLHS, antara lain adalah: dengan pengelolaan hutan, lahan dan sumber air, permasalahan pencemaran air, tanah dan udara, permasalahan lingkungan perkotaan, permasalahan efek gas rumah kaca, masih adanya lahan kritis baik di dalam dan di luar kawasan hutan Jawa Timur, masih adanya gangguan kawasan hutan yang menyebabkan degradasi dan deforestasi kawasan hutan Jawa Timur, belum optimalnya informasi geologi dalam rangka mitigasi bencana geologi, konservasi air tanah, pengembangan dan pemanfaatan potensi air tanah untuk memenuhi kebutuhan masyarakat akan air bersih di daerah sulit air, terjadinya kerusakan lahan dan pencemaran 
lingkungan akibat kegiatan PETI, effisiensi penggunaan energi listrik belum optimal, potensi energi terbarukan cukup besar pengembangan energi panas bumi masih mengalami beberapa kendala, lokasi sebagian berada di kawasan hutan, percepatan peningkatan produksi Gas Bumi untuk pasokan gas di kawasan industri Jawa Timur, terjadi peningkatan konversi lahan pertanian menjadi non pertanian, meningkatnya intensitas usaha tani di daerah hulu aliran sungai yang tidak mengindahkan kaidah-kaidah konservasi tanah dan air, perubahan teknologi dan jumlah penduduk menyebabkan tekanan tersendiri terhadap keseimbangan alam dan iklim pergeseran kondisi alam dan terjadinya berbagai bencana alam untuk menemukan keseimbangan baru, peningkatan kesadaran masyarakat akan kaitan aspek kelestarian lingkungan dalam pengambilan keputusan ekonomi, adanya over capacity sebagian besar prasarana dan sarana perhubungan, pertumbuhan ekonomi yang berkualitas dalam tata niaga ekspor impor khususnya ekspor, negara tujuan memberlakukan green industry, green economy dan eco-labelling, daya saing efisiensi penggunaan bahan baku utama dan penolong serta penggunaan energi melalui konsep produksi bersih meningkatkan daya saing industri dalam negeri, fasilitasi dan pendampingan untuk menuju tercapainya green industry dan green productivity (ramah lingkungan) bagi industri.

Dari hasil identifikasi dan kajian yang telah dilakukan dalam RPJMD Provinsi Jawa Timur diketahui bahwa selama ini peran kawasan strategis provinsi umumnya belum berkembang secara optimal, terutama dalam mendorong perkembangan dan pemerataan pembangunan antarwilayah. Di Provinsi Jawa Timur, saat ini paling-tidak telah ditetapkan empat kawasan agropolitan strategis yang berperan sebagai pusat pertumbuhan wilayah untuk mendorong pengembangan kawasan dalam rangka pemerataan wilayah. Menurut Peraturan Daerah Provinsi Jawa Timur Nomor 5 Tahun 2012 tentang Rencana tata Ruang Wilayah Provinsi Tahun 20112031, beberapa kawasan agropolitan yang diharapkan dapat menjadi pemacu dan pemicu perkembangan dan pemerataan wilayah, antara lain adalah: (1) Cluster Agropolitan Madura yang terdiri dari Kabupaten Bangkalan, Kabupaten Sampang, Kabupaten Pamekasan dan Kabupaten Sumenep; (2) Cluster Agropolitan Ijen yang terdiri dari Kabupaten Jember, Kabupaten Situbondo, Kabupaten Bondowoso, dan Kabupaten Banyuwangi; (3) Cluster Agropolitan Bromo Tengger Semeru yang terdiri dari Kabupaten Malang, Kabupaten Pasuruan, Kabupaten Probolinggo, Kabupaten Lumajang, dan Kabupaten Sidoarjo; dan (4) Cluster Agropolitan Wilis yang terdiri dari Kabupaten Madiun, Kabupaten Magetan, Kabupaten Ngawi, Kabupaten Ponorogo, dan Kabupaten Pacitan, dan Kota Madiun.

Dalam kegiatan ini, cluster yang menjadi fokus pengkajian adalah Cluster Agropolitan Bromo Tengger Semeru yang terdiri dari Kabupaten Malang, Kabupaten Pasuruan, Kabupaten Probolinggo, Kabupaten Lumajang, dan Kabupaten Sidoarjo. Sebagai salah satu kawasan wisata sekaligus sentra pertanian, Taman Nasional Bromo Tengger Semeru (BTS) merupakan kawasan strategis nasional yang memiliki keunikan berupa lautan pasir seluas 5.250 hektar, yang berada pada ketinggian sekitar 2100 meter dari permukaan laut. Di kawasan ini, terdapat 2 gunung yang masih aktif yaitu Gunung Bromo dengan ketinggian 2.392 meter dpl. Gunung Bromo merupakan salah satu destinasi pariwisata terbaik di dunia. Kemudian terdapat juga Gunung Semeru sebagai gunung tertinggi di Pulau Jawa dengan ketinggian 3.676 meter di atas permukaan laut.

Undang-Undang Republik Indonesia Nomor 26 Tahun 2007 tentang Penataan Ruang menyatakan bahwa yang dimaksud dengan Kawasan Agropolitan adalah kawasan yang terdiri atas satu atau lebih pusat kegiatan pada wilayah perdesaan sebagai sistem produksi pertanian dan pengelolaan sumber daya alam tertentu yang ditunjukkan oleh adanya keterkaitan fungsional dan hierarkhi keruangan satuan sistem permukiman dan agribisnis. Kawasan agroplitan pada dasarnya adalah kawasan kota pertanian yang tumbuh dan berkembang hingga mampu melayani, mendorong, menarik dan menghela kegiatan agribisnis di wilayah sekitarnya. Pada kawasan agropolitan terdapat komoditi unggulan, yang dikembangkan dalam sentra 
kegiatan agribisnis, serta usaha penunjang lainnya, sehingga mendorong kawasan tersebut berkembang menjadi kawasan agropolitan (Suyatno, 2008).

Meski pun di atas kertas telah dirumuskan kebijakan dan skenario pengembangan kawasan agropolitan Bromo Tengger Semeru. Tetapi, dalam kenyataan upaya untuk mengembangkan komoditi unggulan dan memanfaatkan kawasan tersebut untuk memacu perkembangan daerah di sekitarnya dan memacu peningkatan kesejahteraan masyarakat, ternyata bukanlah hal yang mudah. Di lapangan, ada berbagai persoalan yang timbul, bukan hanya berkaitan dengan ancaman perubahan perunutkan lahan, tetapi ditengarai juga karena kurangnya dukungan berbagai infrastruktur yang dibutuhkan.

Kegiatan sebagaimana dilaporkan bermaksud mengkaji situasi problematik yang timbul dalam upaya pengembangan kawasan agropolitan Bromo Tengger Semeru, dan sekaligus mengkaji pengaruh kebijakan dan program pembangunan serta merumuskan rekomendasi untuk meningkatkan efektivitas kebijakan yang mendukung implementasi pembangunan yang berkelanjutan di kawasan agropolitan Bromo Tengger Semeru. Kegiatan ini penting dilakukan, terutama untuk lebih memastikan agar perkembangan kawasan agropolitan Bromo Tengger Semeru benar-benar mendukung upaya pemerataan pembangunan antar-wilayah di Provinsi Jawa Timur.

\section{Metode Penelitian}

Studi ini secara keseluruhan dilakukan dalam beberapa tahap. Tahap pertama adalah melakukan kegiatan persiapan atau pra-pelingkupan, yang terdiri atas kegiatan pengidentifikasian isu-isu lingkungan, isu sosial-budaya masyarakat, dan isu-isu ekonomi yang timbul di kawasan agropolitan Bromo Tengger Semeru. Selanjutnya pengumpulan data dan informasi terkait dengan isu-isu, seperti gambaran umum kondisi daerah, hasil-hasil kajian dan publikasipublikasi yang ada, terutama tentang data-data aspek lingkungan hidup kawasan agropolitan Bromo Tengger Semeru. Terakhir, pengidentifikasian jenis dan sumber data yang masih diperlukan, namun belum tersedia agar dapat dilengkapi melalui proses pengumpulan data di lapangan.

Sementara itu, untuk tahap kedua dari kegiatan ini adalah kegiatan pelingkupan, yang meliputi, Verifikasi isu pembangunan berkelanjutan yang timbul berkaitan dengan penetapan kawasan agropolitan Bromo Tengger Semeru sebagai kawasan strategis untuk mendorong pemerataan dan peningkatan kesehateraan masyarakat. Kemudian, penapisan isu-isu lingkungan, isu-isu sosial-budaya dan isu-isu ekonomi dengan menggunakan kriteria sekurang-kurangnya lintas sektor, lintas wilayah, berdampak kumulatif jangka panjang, dan berdampak luas terhadap berbagai pemangku kepentingan. Dan terakhir, Penyepakatan hasil penapisan.

Tahap ketiga, dari kegiatan ini adalah penyusunan Baseline Data. Data yang dibutuhkan dalam kegiatan ini telah dicari dari berbagai dinas/instansi terkait, seperti Bappeda Provinsi Jawa Timur, BPS, Badan Lingkungan Hidup, dan Dinas Pertanian, dinas lain, baik di tingkat provinsi mau pun di tingkat kabupaten. Kegiatan penyusunan baseline data ini didukung dengan kegiatan kajian ke lapangan untuk melengkapi data yang dibutuhkan. Dalam kegiatan ini, daerah yang dijadikan lokasi kajian adalah Kabupaten Malang, Kabupaten Pasuruan, Kabupaten Probolinggo, Kabupaten Lumajang, dan Kabupaten Sidoarjo --yang notabene seтиа adalah bagian dari kawasan agropolitan Bromo Tengger Semeru.

Dalam tahap pengumpulan data ini, tim peneliti telah berkunjung dan mewawancarai secara mendalam (indepth interview) sejumlah nara sumber, baik dari Bappeda kabupaten lokasi kajian, Badan Lingkungan Hidup, Dinas Pertanian, dan instansi terkait yang menangani 
pengembangan kawasan agropolitan Bromo Semeru Tengger. Fokus penggalian data diarahkan pada data tentang potensi sektor pertanian, kondisi kelestarian lingkungan, kondisi sumber daya alam yang ada, dan kebijakan daerah dalam menjaga kelestarian lingkungan dan pengembangan potensi di sektor pertanian.

Tahap keempat adalah melakukan analisis data dan informasi yang berhasil dikumpulkan dari berbagai sumber, baik data primer mau pun data sekunder yang diperoleh dari berbagai lembaga terkait. Pada tahap ini seluruh data dan informasi yang diperoleh telah diolah dan dianalisis sesuai tujuan kegiatan yang telah dirumuskan di muka.

Tahap kelima adalah melakukan pengkajian keterkaitan (antar-wilayah, antar-waktu, antar sektor, antar-pemangku kepentingan), keseimbangan (antar kepentingan ekonomi, sosial, budaya dan lingkungan hidup), dan keadilan (antar kelompok masyarakat dan antar generasi), serta pengkajian pengaruh indikasi program pengembangan wilayah Kawasan Agropolitan Bromo Tengger Semeru.

Tahap keenam, melakukan perumusan alternatif kebijakan dan program. Perumusan alternatif melalui tahap identifikasi langkah-langkah mitigasi/adaptasi, dan/atau alternatif berdasarkan hasil pengkajian keterkaitan, keseimbangan, keadilan, disinergikan dengan isu strategis.

Tahap terakhir adalah rekomendasi perbaikan. Rekomendasi perbaikan KHLS dilakukan berdasarkan hasil dari perumusan mitigasi/adaptasi dan/atau alternatif. Dalam bab penutup ini, selain dikemukakan kembali kesimpulan dari hasil kegiatan yang telah dilakukan, juga dikemukakan sejumlah rekomendasi tentang arah pengembangan kawasan agropolitan Bromo Semeru Tengger di depan.

\section{Hasil dan Pembahasan}

\section{Sejumlah isu prioritas}

Bagi Provinsi Jawa Timur, penetapan Kawasan Agropolitan Bromo Tengger Semeru sesungguhnya bukan hanya untuk memudahkan koordinasi lintas sektoral dan keterpaduan antarwilayah dalam pembangunan di bidang pertanian. Tetapi, juga sekaligus untuk mengintegrasikan dan meningkatkan daya ungkit dari kerjasama antardaerah dalam mempercepat upaya peningkatan kesejahteraan masyarakat.

Dalam upaya pengembangan Kawasan Agropolitan Bromo Tengger Semeru, selain bertujuan untuk menumbuhkembangkan pusat pertumbuhan ekonomi baru berbasis pertanian (agribisnis) di perdesaan dan mewujudkan tata ruang yang menjamin kelestarian lingkungan hidup, yang tak kalah penting adalah bagaimana memastikan perkembangan kawasan itu sekaligus juga mampu membuka kesempatan dan lapangan kerja baru bagi masyarakat perdesaan melalui kegiatankegiatan ekonomi berbasis agribisnis. Selain itu, perkembangan Kawasan Agropolitan Bromo Tengger Semeru diharapkan juga bisa menumbuhkembangkan lembaga-lembaga ekonomi di perdesaan, yang ujung-ujungnya dapat bermanfaat dalam meningkatkan pendapatan masyarakat.

Prinsip dasar yang dijadikan acuan dalam pengembangan Kawasan Agropolitan Bromo Tengger Semeru adalah: Pertama, pengembangan Kawasan Agropolitan Bromo Tengger Semeru merupakan pendekatan pembangunan kawasan perdesaan berbasis agribisnis. Kedua, Pengembangan Kawasan Agropolitan Bromo Tengger Semeru merupakan program utama dan kegiatan terpadu lintas sektor dengan pendekatan yang sifatnya bottom up. Ketiga, penetapan Kawasan Agropolitan Bromo Tengger Semeru dimulai dengan penataan detail kawasan dalam bentuk cetak (blue print) yang menjadi pedoman bagi lima kabupaten di kawasan itu untuk 
menata arah perkembangan dan pemanfaatan wilayahnya. Keempat, perencanaan dan upaya pengembangan Kawasan Agropolitan Bromo Tengger Semeru disusun secara bersama antara instansi pemerintah, masyarakat tani, dan swasta/dunia usaha dan dimasukkan dalam Rencana Pembangunan Jangka Menengah di Pusat dan Rencana Pembangunan Jangka Menengah Daerah di Provinsi, serta RPJMD Kabupaten masing-masing.

Dari hasil kajian lapangan yang dilakukan dan analisis data sekunder, beberapa isu prioritas yang perlu mendapat perhatian pemerintah daerah yaitu; pertama, di berbagai daerah kawasan agropolitan Bromo Tengger Semeru, produktifitas agribisnis masih belum berkembang maksimal, akibat kemampuan sumber daya manusia masih kurang, dan penguasaan teknologi pengolahan pasca panen masih rendah, serta masih ditambah faktor keterbatasan modal usaha, sehingga peningkatan kualitas dan kuantitas produksi sektor agrobisnis masih rendah. Dalam banyak kasus, produk pertanian masih dipasarkan dalam bentuk mentah, dan belum diolah yang memungkinkan produk tersebut memiliki nilai tambah. Kalau pun sebagian produk agribisnis telah diolah dan ditawarkan ke pasar, sebagian besar umumnya masih belum terstandarisasi, sehingga daya saing di pasar dengan skala yang lebih besar --terutama pasar internasional-masih lemah. Di berbagai daerah, umumnya masih belum diterapkan sistem pengemasan dan standarisasi produk yang terjaga. Kualitas tenaga kerja yang terlibat dalam kegiatan agribisnis umumnya masih belum memiliki kemampuan yang memadai, terutama dalam menerapkan teknologi pengolahan pasca panen.

Kedua, para pelaku usaha agribisnis di kawasan agropolitan Bromo Tengger Semeru umumnya tidak memiliki modal mandiri yang cukup, dan secara umum akses mereka pada sumber-sumber pendanaan relatif lemah. Seperti lazim terjadi di masyarakat pedesaan, sumber pendanaan yang relatif mudah diakses masyarakat adalah rentenir, tengkulak, bank thithil dan berbagai pelepas uang informal lain yang acapkali menetapkan suku bunga pinjaman yang tinggi. Akses masyarakat petani pada sumber pendanaan lunak, dalam banyak kasus kurang, sehingga membatasi peluang mereka untuk meningkatkan produksi dan akses pada pasar yang lebih luas.

Ketiga, kegiatan pemasaran berbagai produk agribisnis umumnya masih melalui jalur pasar tradisional atau konvensional, ditambah ketersediaan pasar/terminal agribisnis belum memadai, sehingga menjadi penyebab kurangnya promosi produk agribisnis yang dihasilkan masyarakat di kawasan agropolitan Bromo Tengger Semeru. Posisi tawar petani sebagai penghasil produk agribisnis acapkali masih lemah, dan menjadi korban dominasi para tengkulak atau pedagang perantara yang memiliki kekuatan besar di bidanf permodalan dan akses pada pasar.

Keempat, dukungan prasarana dan infrastruktur untuk menunjang kegiatan agrobisnis umumnya masih belum tersedia secara layak. Kondisi jalan, saluran irigasi dan berbagai lembaga yang dibutuhkan untuk mendukung pengembangan produktifitas komoditi pertanian umumnya masih belum tersedia sesuai kebutuhan. Model dan pendekatan pembangunan yang sebelumnya masih cenderung menempatkan wilayah urban sebagai pusat pertumbuhan, seringkali menyebabkan wilayah pedesaan yang merupakan kawasan utama untuk kegiatan agribisnis menjadi tertinggal.

Kelima, komoditi pertanian yang dihasilkan dan menjadi andalan masyarakat yang menekuni usaha agribisnis, seringkali masih rentan waktu dan belum diolah, sehingga tidak memiliki nilai tambah yang signifikan bagi petani. Berbagai komoditi dan produk hasil panenan yang dihasilkan masyarakat di kawasan Agropolitan Bromo Tengger Semeru umumnya masih banyak dijual dalam bentuk mentahan, sehingga tidak memiliki daya saing yang kuat di pasaran.

\section{Kendala dan strategi pengembangan kawasan agropolitan}

Dari hasil wawancara di lapangan tehadap sejumlah nara sumber atau informan dari berbagai SKPD, diketahui ada berbagai kendala yang dihadapi Pemerintah Daerah Kabupaten maupun 
Pemerintah Provinsi Jawa Timur dalam upaya pengembangan kawasan agropolitan Bromo Tengger Semeru. Sebagaiana tertera pada tabel tabel 1.

Tabel 1.

Kendala dan Strategi dalam Pengembangan Kawasan Lingkungan di Lima Kabupaten (Malang, Lumajang, Pasuruan, Probolinggo, Sidoarjo) Provinsi Jawa Timur 2015

\begin{tabular}{|c|c|}
\hline Kendala & Strategi \\
\hline $\begin{array}{c}\text { Koordinasi antar Bupati kurang maksimal } \\
\text { dan komitmen }\end{array}$ & $\begin{array}{l}\text { Political will dan koordinasi antar Bupati } \\
\text { ditingkatkan dan diagendakan rutin. }\end{array}$ \\
\hline $\begin{array}{c}\text { Penetapan unggulan produk agro } \\
\text { unggulan kurang maksimal sebagai } \\
\text { wilayah kawasan. }\end{array}$ & $\begin{array}{l}\text { Tiap tahun evaluasi produk unggulan yang } \\
\text { ditawarkan. }\end{array}$ \\
\hline $\begin{array}{l}\text { Tiap kabupaten mempunyai unggulan } \\
\text { masing-masing. }\end{array}$ & $\begin{array}{l}\text { Pemetaan produk agro per kabupaten dan } \\
\text { kawasan. }\end{array}$ \\
\hline $\begin{array}{c}\text { Arah konsep agropolitan kawasan kurang } \\
\text { jelas keuntungan ekonomi, sosial } \\
\text { budayanya }\end{array}$ & $\begin{array}{l}\text { Penetapan arah dengan MOU antar Bupati } \\
\text { dengan koordinator Bappeda Provinsi. }\end{array}$ \\
\hline $\begin{array}{l}\text { Pejabat yang datang pada koordinasi } \\
\text { sering bergantian dan menghambat } \\
\text { pengambilan keputusan. }\end{array}$ & $\begin{array}{c}\text { Komitmen dan penetapan langsung dengan } \\
\text { bupati-bupati (tidak asal diwakilkan) }\end{array}$ \\
\hline $\begin{array}{l}\text { Produk kemasan dan produk hasil kurang } \\
\text { kualitas yang berstandar. }\end{array}$ & Pelibatan dinas/instansi terkait. \\
\hline $\begin{array}{l}\text { Pembinaan UKM, kelompok usaha } \\
\text { bersama, BUMN kurang maksimal. }\end{array}$ & $\begin{array}{c}\text { Agenda rutin dan terpadu dengan } \\
\text { melibatkan profesional terkait bidang } \\
\text { keahlian. }\end{array}$ \\
\hline $\begin{array}{c}\text { Pengembangan infrastruktur jalan kurang } \\
\text { maksimal sehingga pengiriman produk } \\
\text { terjebak gangguan lalu lintas (kasus } \\
\text { Puspo Agro Pasar Sidoarjo). }\end{array}$ & $\begin{array}{l}\text { Mengutamakan kepentingan masyarakat } \\
\text { daripada kepentingan proyek. }\end{array}$ \\
\hline $\begin{array}{l}\text { Kurang pengembangan kawasan wisata } \\
\text { rumah tangga dengan keterlibatan } \\
\text { langsung wisatawan pada aktivitas } \\
\text { perkebunan / pertanian. }\end{array}$ & $\begin{array}{l}\text { Menginventarisasi dan membuka peluang } \\
\text { wisata pendidikan rumah tangga pertanian } \\
\text { dan perkebunan, pelatihan. }\end{array}$ \\
\hline $\begin{array}{l}\text { Kurang memanfaatkan Corporate Social } \\
\text { Responsibility (CSR) industri besar. }\end{array}$ & $\begin{array}{l}\text { Pelibatan industri besar tentang CSR } \\
\text { karena pemanfaatan CSR selama ini belum } \\
\text { maksimal. }\end{array}$ \\
\hline $\begin{array}{c}\text { Kurang memaksimalkan wisata } \\
\text { pantai/pesisir, hutan, mangrove, sungai, } \\
\text { waduk, taman, museum }\end{array}$ & $\begin{array}{c}\text { Menginventarisasi dan melatih masyarakat } \\
\text { pantai, pelibatan nelayan dalam } \\
\text { perdagangan suvenir hasil laut dan kuliner, } \\
\text { memaksimalkan promo lewat travel wisata } \\
\text { dan instansi terkait }\end{array}$ \\
\hline $\begin{array}{c}\text { Kurang mendorong } \\
\text { kewirausahaan/pelatihan temporer. }\end{array}$ & $\begin{array}{l}\text { Rutin diagendakan dengan dana CSR dan } \\
\text { swadaya lokal. }\end{array}$ \\
\hline $\begin{array}{c}\text { Kurang sosialisasi, implementasi dan } \\
\text { koordinasi RTRW/Rencana Tata Ruang } \\
\text { Wilayah level provinsi Jawa Timur } \\
\text { kepada kabupaten }\end{array}$ & $\begin{array}{c}\text { Peningkatan sosialisasi (RTRW) dan } \\
\text { koordinasi serta pemantauan implementasi } \\
\text { yang saling menguntungkan untuk } \\
\text { kabupaten dan provinsi }\end{array}$ \\
\hline $\begin{array}{c}\text { Ketidakjelasan keuntungan ekonomi bagi } \\
\text { masyarakat lokal. }\end{array}$ & $\begin{array}{c}\text { Kebijakan memproteksi } \\
\text { petani/nelayan/pengusaha/UKM lokal } \\
\text { terkait pengembangan agar merugi tidak } \\
\text { merugi. }\end{array}$ \\
\hline Data-data SKPD kurang valid. & $\begin{array}{c}\text { Pemetaan dan kajian lebih berdasar data } \\
\text { lapangan secara rinci }\end{array}$ \\
\hline
\end{tabular}

Sumber: Wawancara mendalam kepada sejumlah informan dan diolah, 2015. 


\section{Kebijakan pengembangan kawasan agropolitan ke depan}

Kebijakan dan arah pengembangan kawasan agropolitan Bromo Tengger Semeru pada dasarnya adalah upaya pengembangan sebuah kawasan yang dilakukan secara komprehensif, melibatkan keterpaduan kepentingan berbagai daerah dan masyarakat, menerapkan keterpaduan dari berbagai aspek, mulai dari potensi sumber daya alam yang ada, khususnya pertanian, kesiapan sumber daya manusia, dan berbagai lembaga sosial-ekonomi pendukungnya.

Pengembangan sebuah kawasan agropolitan tidak hanya diarahkan pada kemajuan wilayahwilayah yang menjadi pusat pertumbuhan, tetapi justru yang terpenting kemajuan seluruh daerah yang tergabung dalam kawasan agropolitan harus dikembangkan dengan prinsip simbiosis mutualisme alias saling menguntungkan. Pengembangan kawasan agropolitan tidak diarahkan secara sentralistik, karena tujuan pengembangan kawasan agropolitan sesungguhnya adalah untuk mempercepat upaya pemerataan pembangunan dan kemajuan wilayah, serta pemerataan peningkatan kesejahteraan masyarakat.

Berikut program prioritas yang perlu dikembangkan untuk mendukung pengembangan kawasan agropolitan Bromo Tengger Semeru, Sebagaiana tertera pada tabel tabel 2.

Tabel 2.

Program Pengembangan Kawasan Agropolitan Bromo Tengger Semeru Program Keterangan

\begin{tabular}{|c|c|}
\hline Program & Keterangan \\
\hline $\begin{array}{c}\text { Pembangunan sarana dan } \\
\text { prasarana }\end{array}$ & $\begin{array}{c}\text { Pengembangan Sub terminal Agribisnis. } \\
\text { Pengembangan unit penghasil pupuk organik dan pupuk } \\
\text { kandang. } \\
\text { Penyediaan bibit unggul bagi petani. } \\
\text { Pengembangan peran Balai Benih dan Bibit Hortikultura. } \\
\text { Pengembangan industri mikro-kecil pengolah komoditi } \\
\text { unggulan di bidang agrobisnis. }\end{array}$ \\
\hline $\begin{array}{c}\text { Pemberdayaan } \\
\text { kelembagaan dan SDM } \\
\text { local }\end{array}$ & $\begin{array}{c}\text { Pelatihan dan pengembangan kelompok tani, koperasi, dan } \\
\text { pelaku UMKM di bidang agrobisnis. } \\
\text { Pelatihan diversifikasi produk, dan manajemen bagi petani } \\
\text { dan pelaku UMKM di bidang agrobisnis. } \\
\text { Revitalisasi fungsi Kopertan. }\end{array}$ \\
\hline $\begin{array}{c}\text { Peningkatan aksesibilitas } \\
\text { dan utilitas }\end{array}$ & $\begin{array}{l}\text { Penambahan rute angkutan umum dari daerah produksi dan } \\
\text { daerah pengolahan dan pasar. } \\
\text { Pengelolaan sistem irigasi teknis melalui pemerataan jaringan } \\
\text { perpipaan transmisi dan distribusi, dan reservoir distribusi. } \\
\text { Perbaikan, pelebaran dan pengembangan jaringan jalan. }\end{array}$ \\
\hline $\begin{array}{l}\text { Promosi dan daya tarik } \\
\text { bagi investor }\end{array}$ & $\begin{array}{l}\text { Kemudahan layanan perijinan dan insentif bagi calon investor } \\
\text { agar menanamkan modal usaha di kawasan agropolitan } \\
\text { Bromo Tengger Semeru. } \\
\text { Promosi produk agrobisnis, baik melalui pameran mau pun } \\
\text { melalui penyediaan outlet bagi produk pertanian. }\end{array}$ \\
\hline Pengolahan pasca panen & $\begin{array}{c}\text { Bantuan permodalan untuk usaha pengolahan hasil pertanian. } \\
\text { Pelatihan dan penerapan teknologi pengolahan pasca panen. } \\
\text { Keterkaitan antara pengolahan dan pemasaran produk } \\
\text { pertanian olahan. }\end{array}$ \\
\hline
\end{tabular}

Kebijakan dan upaya pengembangan kawasan Agropolitan Bromo Tengger Semeru secara garis besar direkomendasikan untuk dikembangkan ke hal-hal sebagai berikut: Pertama, untuk mempercepat akselerasi pengembangan Kawasan Agropolitan Bromo Tengger Semeru, salah satu prasyarat yang dibutuhkan tak pelak adalah dukungan sarana dan prasarana yang memadai. Di berbagai kabupaten yang menjadi bagian dari Kawasan Agropolitan Bromo Tengger Semeru, 
Kabupaten Lumajang, Malang, Probolinggo, Pasuruan dan Sidoarjo, selama ini harus diakui bahwa kualitas dan jumlah sarana dan prasarana yang tersedia relatif berbeda-beda, dan belum semua mendukung upaya pengembangan potensi masing-masing daerah. Kondisi lalu-lintas Jalan Raya Porong yang mengalami hambatan sejak munculnya lumpur Lapindo yang tidak juga berkesudahan hingga saat ini, langsung mau pun tidak langsung menyebabkan arus perdagangan atau pemasaran komoditi unggulan pertanian daerah menjadi terganggu yang ujung-ujungnya menyebabkan inefisiensi dalam biaya pengiriman komoditi yang bersangkutan.

Meski telah dibangun jalan arteri Porong alternatif, dan telah pula dioperasikan jalan tol baru di sekitar Pandaan, tetapi secara umum kemacetan masih menjadi ancaman bagi kelancaran pengiriman komoditi unggulan daerah, terlebih pada musim hujan. Pada musim hujan, kemungkinan terjadinya luapan lumpur dari semburan lumpur Lapinda, bukan hanya mengancam kelancaran arus kereta api di daerah itu, tetapi juga berpotensi menganggu kelancaran arus lalu-lintas kendaraan bermotor. Dengan pembangunan sarana dan prasarana yang memadai, diharapkan pemasaran produk-produk unggulan di Kawasan Agropolitan Bromo Tengger Semeru dapat lebih efisien serta sekaligus memperkecil resiko kemungkinan terjadinya kerusakan produk unggulan di bidang pertanian sebelum bisa dijual ke pasar.

Selain kelancaran lalu-lintas Jalan Raya Porong, sarana dan prasarana lain yang dibutuhkan untuk mendukung pengembangan Kawasan Agropolitan Bromo Tengger Semeru adalah pembenahan dan pembangunan jalan-jalan yang menghubungkan sentra-sentra komoditi unggulan dengan pasar, pembangunan gudang, fasilitas telekomunikasi, dan lain-lain. Kesulitan untuk mengangkut hasil panenan dari sentra produksi ke pasar, jelas akan menjadi penghambat kelancaran pemasaran. Di sisi lain, isu tentang kelangkaan pupuk, dukungan saluran irigasi yang memadai, dan lain-lain, juga beberapa kali dikemukakan sejumlah informan sebagai hal yang perlu mendapat perhatian demi kemajuan pengembangan Kawasan Agropolitan Bromo Tengger Semeru.

Kedua, untuk mendukung pengembangan produk-produk pertanian unggulan di masing-masing daerah, selain dibutuhkan kerjasama dengan para pelaku UMKM, yang tak kalah penting adalah bagaimana mendorong agar produk-produk unggulan pertanian dari masing-masing daerah dapat menembus pasar yang lebih luas, minimal pada skala pasar regional, nasional atau bahkan pasar internasional. Produk unggulan Kabupaten Lumajang, seperti pisang dan produk olahannya seperti kripik pisang, misalnya, perlu didukung perkembangannya agar dapat menjadi pemasok utama pasar regional atau pasar nasional dengan cara mendorong peningkatan volume produksi, dan kualitas produk olahan melalui program diversifikasi produk olahan yang berkualitas dan sesuai dengan selera pasar atau konsumen.

Kedua, pemberdayaan masyarakat di Kawasan Agropolitan Bromo Tengger Semeru diharapkan tidak saja diarahkan pada upaya peningkatan produksi dan produktifitas komoditi pertanian, tetapi juga pada pengembangan usaha dan sistem agribisnis lainnya yang mendukung usaha agrobisnis komoditi unggulan kawasan agropolitan, baik itu agribinis hulu (agroinput), agribisnis hilir (pemasaran pengolahan hasil, sortasi dan grading) serta industri jasa dan pelayanan yang berkaitan dengan komoditi pertanian yang ada.

Ketiga, di lingkungan Kawasan Agropolitan Bromo Tengger Semeru, salah satu potensi di sektor pariwisata yang sangat besar adalah kawasan wisata Gunung Bromo. Upaya pengembangan berbagai produk unggulan daerah, oleh sebab itu akan sangat baik jika diarahkan untuk mendukung upaya pengembangan kawasan wisata Gunung Bromo, baik dalam bentuk produk-produk olahan hasil pertanian unggulan, maupun dalam bentuk pengembangan sarana dan prasarana yang memadai. Perlu disadari bahwa kelemahan dari kawasan wisata Gunung Bromo dibandingkan dengan daerah tujuan wisata lain, seperti Yogyakarta, atau terlebih Bali adalah karena paket daya tarik wisata yang ditawarkan belum sepenuhnya lengkap. Sebuah 
kawasan wisata, niscaya tidak akan mampu menarik pesona wisatawan jika tidak mampu menawarkan pesona-pesona alam yang menarik, dan fasilitas pendukung yang memadai, seperti jalan penghubung yang layak, fasilitas perhotelan yang menarik, tawaran aktivitas kegiatan selama orang berwisata, dan juga yang tak kalah penting produk cinderata mata dan oleh-oleh seperti produk makanan khas lokal.

Keempat, dalam rangka mendorong percepatan pengembangan Kawasan Agropolitan Bromo Tengger Semeru, ada baiknya jika didukung dengan pengembangan sistem klaster untuk komoditi-komoditi unggulan tertentu, karena dengan terbentuknya sistem klaster diharapkan akan diikuti dengan terbentuknya kelompok masyarakat sesama pelaku usaha komoditi tertentu. Meski pun sistem klaster beresiko memungkinkan terjadinya persaingan yang lebih ketat di antara sesama pelaku usaha dalam komoditi yang sama, tetapi dengan dibentuk kelompok bersama diharapkan akan dapat meningkatkan posisi bargaining mereka ketika harus menghadapi tengkulak, pedagang perantara atau konsumen lainnya. Dengan sistem klaster, maka masing-masing pihak akan memungkinkan dapat memperoleh harga bahan baku lebih murah, dan dengan dibentuk kelompok bersama diharapkan akan dapat terbentuk lembaga bersama yang menyepakati harga jual yang relatif dalam batas-batas yang tetap menguntungkan, dan sekaligus mendorong tumbuhnya iklim persaingan yang sehat dan efisien di antara sesama pelaku usaha agropolitan yang ada di daerah. Para pelaku usaha agrobis di Kawasan Agropolitan Bromo Tengger Semeru bukan hanya perlu didukung kebutuhan modal usaha mereka, tetapi juga kebutuhan akan sarana produksi, mulai dari pupuk, benih, dan lain-lain dengan harga yang terjangkau, dekat dan mudah diakses, serta tersedia dalam jumlah yang cukup. Di masing-masing daerah akan jauh lebih baik jika upaya pengembangan sektor pertanian juga didukung kelembagaan perkreditan atau Lembaga Keuangan Mikro yang bisa diakses dan memiliki sifat yang fleksibel.

Kelima, agar upaya pengembangan komoditi unggulan di Kawasan Agropolitan Bromo Tengger Semeru dapat berjalan maksimal, maka salah satu prasyarat yang dibutuhkan adalah dukungan kualitas sumber daya manusia yang memadai. Untuk itu, ke depan selain dibutuhkan dukungan pelatihan ketrampilan dan meningkatan kualitas standarisasi produk agropolitan, yang tak kalah penting adalah dukungan sumber daya manusia yang benar-benar inovatif dan kreatif dalam mengolah dan memberi nilai tambah atas produk agropolitan yang mereka hasilkan. Usaha di bidang pertanian yang dikembangkan di Kawasan Agropolitan Bromo Tengger Semeru seyogianya diarahkan pada pengolahan hasil pertanian yang seminimal mungkin bebas dari limbah, dan tetap mendukung arti penting kelestarian lingkungan. Di kalangan pelaku usaha di sektor pertanian, ke depan mereka tentu harus ditingkatkan kualitasnya agar dapat menghasilkan produk komoditi pertanian dan produk olahan hasil pertanian yang lebih bernilai, dan memiliki nilai tukar yang menguntungkan petani. Dukungan dan kegiatan pelatihan yang dikembangkan kepada para pelaku usaha komoditi pertanian dan produk olahan hasil pertanian perlu terus dilaksanakan, terutama agar mereka memiliki kualitas, kreativitas dan sikap inovatif dalam mencari ceruk-ceruk pangsa pasar baru yang menguntungkan. Di era global seperti sekarang ini, terutama kehadiran MEA, tidak bisa lagi ditunda tuntutan agar para pelaku usaha agropolitan benar-benar memiliki kualitas sumber daya manusia yang memadai, karena usaha yang mampu bertahan di era persaingan yang makin ketat, tak pelak adalah usaha yang didukung kualitas sumber daya manusia yang kreatif dan inovatif.

Keenam, untuk mempercepat upaya pembangunan di Kawasan Agropolitan Bromo Tengger Semeru, selain mengandalkan dukungan dana APBN dan APBD, yang tak kalah penting adalah dukungan dana dan keterlibatan berbagai pihak, termasuk kekuatan swasta komersial dan pihak perusahaan besar lainnya. Selama ini, perkembangan sektor-sektor unggulan di berbagai daerah, seringkali terbatas jika hanya mengandalkan dukungan pemerintah. Oleh sebab itu, dengan melibatkan dukungan kekuatan swasta dan berbagai pihak lain, diharapkan akselerasi perkembangan sektor-sektor unggulan di Kawasan Agropolitan Bromo Tengger Semeru akan 
dapat bergerak lebih cepat. Yang terpenting adalah bagaimana memastikan agar percepatan perkembangan sektor-sektor unggulan di daerah tetap melibatkan peran serta masyarakat lokal, sehingga hasilnya dapat bermanfaat dalam meningkatkan taraf kesejahteraan masyarakat setempat.

Ketujuh, di masing-masing kabupaten, akan jauh lebih baik jika memiliki lembaga yang secara khusus diserahi tanggungjawab untuk mendukung upaya pengembangan Kawasan Agropolitan Bromo Tengger Semeru secara terpadu di bawah koordinasi Bakorwil yang ada. Kerjasama kelembagaan ini dibutuhkan, terutama untuk mencegah agar tidak muncul regulasi yang tumpang-tindih, saling menghambat, yang dapat bersifat kontra-produktif bagi kemajuan dan pengembangan Kawasan Agropolitan Bromo Tengger Semeru. Sementara itu, di kalangan para pelaku usaha agribis, seyogianya juga perlu memiliki kelembagaan yang dapat menjadi sentra bagi proses pembelajaran dan pengembangan komoditi unggulan lokal yang berkualitas dan berdaya saing. Melakukan revitalisasi terhadap institusi-institusi lokal yang memiliki akar kultural, perlu terus dilakukan sebagai media bagi petani dan pelaku usaha agrobis untuk meningkatkan kegiatan usaha dan kelangsungan kehidupannya. Di samping itu, di masingmasing daerah ada baiknya pula jika dikembangkan sub-sub terminal produk agrobis dan pusat lelang hasil pertanian yang dapat dimanfaatkan para petani untuk memasarkan produk pertanian yang mereka hasilkan.

Kedelapan, di kalangan para pelaku usaha agropolitan, niscaya perkembangannya ke depan akan lebih jika didukung keterkaitan pasar lokal dengan pasar yang lebih luas, serta kerjasama yang sinergistik dengan daerah lain. Yang dimaksud kerjasama sinergistik di sini adalah pembagian kerja yang benar-benar tertata tentang arah pengembangan komoditi unggulan apa yang menjadi kekhasan dan andalan masing-masing daerah, dan bagaimana mencegah agar pengembangan komoditi unggulan masing-masing daerah tidak saling mematikan.

Kesembilan, untuk menjaga kontinuitas kelangsungan usaha agrobis, selain perlu dipastikan ketersediaan lahan produktif yang cukup dengan cara mencegah konversi lahan produktif dan penciptaan lahan-lahan produktif baru, yang tak kalah penting adalah pendidikan pertanian bagi generasi muda agar mereka tidak selalu silau untuk mencari pekerjaan lain di luar sektor pertanian. Di kalangan petani, proses regenerasi ini perlu mendapat perhatian serius, sebab ada indikasi di kalangan generasi muda minat mereka untuk meneruskan usaha orang tuanya mulai berkurang, sehingga tanpa adanya dukungan atau dorongan yang memfasilitasi tumbuhnya embrio-embiro petani baru pada generasi sekarang ini, dikhawatirkan ke depan kemampuan daerah untuk menghasilkan produk-produk pertanian yang berkualitas menjadi menurun drastis.

\section{Rekomendasi program utama}

Untuk memastikan agar upaya pengebangan kawasan agropolitan Bromo Tengger Semeru benar-benar memberikan manfaat bagi peningkatan taraf kesejahteraan masyarakat, hal terpenting adalah bagaimana mendorong agar petani dan masyarakat miskin di kawasan tersebut dapat memperoleh pembagian margin keuntungan yang lebih proporsional, dan usaha yang mereka tekuni dapat diandalkan sebagai mata pencaharian yang menguntungkan masyarakat. Dalam hal ini, ada beberapa program utama yang perlu memperoleh perhatian:

Pertama, di kawasan agropolitan Bromo Tengger Semeru, perkembangan sektor pertanian di wilayah yang telah ditetapkan perlu didukung dengan perkembangan daerah penunjang, yaitu kawasan "agro eco industrial" yang berperan mendukung pengolahan produk pertanian menjadi produk olahan pertanian di tahap pasca panen yang memiliki "nilai tambah" lebih bagi petani. Selama ini, di pasaran harga komoditi pertanian dalam bentuk mentah umumnya tidak terlalu menguntungkan petani, dan posisi tawar petani juga rata-rata rendah di hadapan tengkulak atau pedagang perantara karena sifat komoditi yang dihasilkan rentan waktu. Dengan memberi nilai 
tambah, atau mengolah komoditi pertanian menjadi produk-produk yang lebih bernilai dan tidak cepat rusak/busuk, maka diharapkan posisi tawar petani dalam penentuan harga jual produk mereka akan lebih baik. Selain itu, untuk meningkatkan prospek pemasaran komoditi pertanian unggulan masyarakat di kawasan agropolitan Bromo Tengger Semeru, yang tak kalah penting adalah mendorong masyarakat lokal untuk mengembangkan diversifikasi produk --dengan harapan untuk menjangkau pangsa pasar yang lebih beragam dan luas. Sudah barang tentu, untuk mewujudkan hal ini, pemerintah daerah perlu mendukung dengan memberikan program pelatihan ketrampilan dan bkal-bekal keahlian lain yang bisa dimanfaatkan masyarakat untuk mengembangkan diversifikasi produk yang makin beragam sesuai selera masyarakat konsumen.

Kedua, untuk memastikan agar pengembangan kawasan agropolitan Bromo Tengger Semeru tidak kontra-produktif bagi kepentingan peningkatan taraf kesejahteraan petani, salah satu yang perlu diperhatikan adalah kesiapan kelembagaan petani yang efektif untuk mencegah terjadinya persaingan yang tidak sehat di antara petani sendiri dalam penentuan harga jual komoditi agrobisnis yang mereka hasilkan. Di berbagai daerah, diketahui masih sering terjadi antara petani satu dengan yang lain tidak kompak dalam penentuan harga jual, dan rentan menjadi objek perpecehan tindakan para pedagang perantara atau pembeli komoditi mentah mereka. Ketidakkompakan petani dalam penentuan harga ini, sering menjadi titik lemah yang menyebabkan harga jual komoditi pertanian yang dihasilkan petani menjadi rendah atau palingtidak kurng sepadan dengan biaya produksi yang telah mereka keluarkan. Untuk memastikan agar di antara petani tidak terjadi persaingan yang tidak sehat, oleh sebab itu penataan kelembagaan kelompok tani menjadi salah satu prasyarat yang penting.

Ketiga, upaya pengembangan kawasan agopolitan Bromo Tengger Semeru ke depan diharapkan tidak hanya menekankan pada perkembangan komoditi pertanian unggulan di masing-masing daerah, tetapi yang tak kalah penting juga memperhatikan ketersediaan infrastruktur penunjangnya, seperti lembaga perbankan, pasar, jaringan jalan, dan lain-lain. Kondisi infrastruktur yang kurang mendukung, dalam banyak hal akan menyebabkan pemasaran komoditi pertanian yang dihasilkan petani menjadi terbatas. Di tengah iklim persaingan yang makin ketat, perlu disadari bahwa untuk mendongkrak pemasaran komoditi pertanian mau ppun komoditi olahan hasil pertanian tidaklah akan dapat berkembang maksimal jika tidak didukung ketersediaan infrastruktur dan lembaga yang terkait. Untuk memenuhi kebutuhan modal usaha, misalnya, niscaya tidak akan dapat hanya mengandalkan pada dana simpanan petani, sehingga mau tidak mau harus ada lembaga perkreditan desa yang benar-benar pro-petani, dan mau memahami karakteristik kebutuhan dan kemampuan petani secara keseluruhan. Sebagaimana yang tertera pada tabel 3 .

Keempat, untuk memastikan agar pengembangan kawasan agropolitan Bromo Tengger Semeru tidak malah mendorong terjadinya polarisasi sosial-ekonomi dan malah mematikan potensi swakarsa masyarakat lokal, yang terpenting adalah bagaimana mempersiapkan perkembangan modal sosial sebagai fondasi utama perubahan ke depan. Sekali legi perlu disadari bahwa tujuan pengembangan kawasan Agropolitan Bromo Tengger Semeru adalah untuk kepentingan utama masyarakat, sehingga untuk mencegah agar hasil-hasil pembangunan kawasan tidak jatuh atau hanya dinikmati kelompok masyarakat yang memiliki kekuatan ekonomi dan kekuasaan, maka sejak awal perlu dipersiapkan pengembangan dan pemberdayaan kualitas SDM masyarakat lokal, khususnya masyarakat miskin agar mereka dapat ikut terlibat dalam pelaksanaan program pembangunan dan perubahan yang berlangsung di dalamnya. Jangan sampai terjadi, ketika sebuah potensi di sektor pertanian dikembangkan, tetapi yang terjadi kemudian pihak yang memetik keuntungan terbesar justru kelompok pedagang perantara atau tengkulak yang notabene merupakan pihak yang acapkali lebih dominan dalam penentuan harga --yang seringkali memperoleh margin keuntungan terbesar dalam mata rantai perdagangan komoditi pertanian. 
Tabel 3.

Strategi dan Program Pengembangan Kawasan Agropolitan Bromo Tengger Semeru

\begin{tabular}{|c|c|c|c|c|c|}
\hline Kabupaten & Lokasi & Keterangan & $\begin{array}{l}\text { Komoditas } \\
\text { Unggulan }\end{array}$ & $\begin{array}{c}\text { Infrastruktur } \\
\text { dan Program } \\
\text { yang } \\
\text { Dibutuhkan }\end{array}$ & $\begin{array}{l}\text { Strategi dan } \\
\text { Program } \\
\text { Pengembanga } \\
\text { n Agropolitan }\end{array}$ \\
\hline Malang & $\begin{array}{c}\text { Kecamata } \\
\text { n } \\
\text { Poncokus } \\
\text { umo }\end{array}$ & $\begin{array}{c}17 \text { desa, luas } \\
\text { lahan } 19.688 \\
\text { Ha, jumlah } \\
\text { penduduk } \\
93.372 \text { jiwa } \\
\text { (2011) }\end{array}$ & $\begin{array}{c}\text { Apel, padi, } \\
\text { jagung, } \\
\text { bawang } \\
\text { merah, } \\
\text { bawang prei, } \\
\text { blimbing, } \\
\text { bunga krisan, } \\
\text { cabe, kentang, } \\
\text { wortel, } \\
\text { kelengkeng, } \\
\text { labu siam, } \\
\text { tomat, kubis, } \\
\text { manisa, } \\
\text { pepaya, sapi } \\
\text { potong dan } \\
\text { sapi perah }\end{array}$ & $\begin{array}{c}\text { Perbaikan dan } \\
\text { pelebaran } \\
\text { sarana jalan } \\
\text { untuk } \\
\text { mendukung } \\
\text { pemasaran } \\
\text { dan } \\
\text { keterkaitan } \\
\text { antara sektor } \\
\text { pertanian } \\
\text { dengan } \\
\text { industri } \\
\text { pengolahan } \\
\text { produk } \\
\text { pertanian } \\
\\
\text { Penyediaan } \\
\text { lembaga } \\
\text { perkreditan } \\
\text { dengan } \\
\text { prosedur dan } \\
\text { beban suku } \\
\text { bunga yang } \\
\text { terjangkau } \\
\text { petani }\end{array}$ & $\begin{array}{l}\text { Pengembangan } \\
\text { kawasan } \\
\text { agropolitan } \\
\text { yang didukung } \\
\text { oleh } \\
\text { pembangunan } \\
\text { agro eco } \\
\text { industrial. }\end{array}$ \\
\hline Lumajang & $\begin{array}{l}\text { Kecamata } \\
n \\
\text { Senduro } \\
\text { dan } \\
\text { Pasrujam } \\
\text { be }\end{array}$ & $\begin{array}{c}\text { Jumlah desa } \\
19, \text { luas } \\
\text { lahan 119,98 } \\
\text { Km2, jumlah } \\
\text { penduduk } \\
78.276 \text { jiwa } \\
\text { (2011) }\end{array}$ & $\begin{array}{l}\text { Pisang agung } \\
\text { Semeru, dan } \\
\text { pisang mas } \\
\text { kirana, } \\
\text { manggis, } \\
\text { kentang, } \\
\text { wortel, kopi, } \\
\text { kayu sengon, } \\
\text { kambing } \\
\text { etawa, sapi } \\
\text { perah }\end{array}$ & $\begin{array}{c}\text { Pembangunan } \\
\text { jalan poros } \\
\text { desa, pasar } \\
\text { agro. } \\
\text { Perlu pelatihan } \\
\text { dan } \\
\text { pembangunan } \\
\text { industri } \\
\text { pengolahan } \\
\text { komoditas } \\
\text { pisang agung } \\
\text { menjadi kripik } \\
\text { pisang dan } \\
\text { packing untuk } \\
\text { pisang mas } \\
\text { kirana }\end{array}$ & $\begin{array}{l}\text { Perlu didukung } \\
\text { penataan } \\
\text { kelembagaan } \\
\text { kelompok tani } \\
\text { pisang agung } \\
\text { maupun pisang } \\
\text { mas kirana } \\
\text { untuk } \\
\text { mencegah } \\
\text { terjadinya } \\
\text { persaingan } \\
\text { harga yang } \\
\text { merugikan } \\
\text { petani }\end{array}$ \\
\hline Probolinggo & $\begin{array}{l}\text { Kecamata } \\
\text { n Gading, } \\
\text { Tiris, } \\
\text { Krucil, } \\
\text { Sukapura, } \\
\text { Sumber, } \\
\text { Tongas, } \\
\text { dan } \\
\text { Lumbang }\end{array}$ & $\begin{array}{c}94 \text { desa, luas } \\
\text { lahan } \\
115.217,34 \\
\text { Ha, jumlah } \\
\text { penduduk } \\
\text { 303.729 jiwa } \\
\text { (2010) }\end{array}$ & $\begin{array}{c}\text { Kentang, } \\
\text { manggis, } \\
\text { kentang, } \\
\text { mangga, } \\
\text { cengkeh, } \\
\text { kakao, sapi } \\
\text { perah. } \\
\text { Pengembanga } \\
\text { n pusat } \\
\text { pembenihan }\end{array}$ & $\begin{array}{c}\text { Penyediaan } \\
\text { pupuk organik, } \\
\text { peningkatan } \\
\text { kualitas } \\
\text { teknolopgi } \\
\text { penanaman, } \\
\text { penyediaan } \\
\text { pakan ternak. } \\
\text { Kegiatan }\end{array}$ & $\begin{array}{l}\text { Pengembangan } \\
\text { nilai tambah } \\
\text { komoditi produk } \\
\text { unggulan } \\
\text { menjadi } \\
\text { komoditi olahan } \\
\text { yang } \\
\text { bermanfaat } \\
\text { dalam } \\
\text { meningkatkan }\end{array}$ \\
\hline
\end{tabular}




\begin{tabular}{|c|c|c|c|c|c|}
\hline & & & $\begin{array}{l}\text { bibit manggis, } \\
\text { mangga, dan } \\
\text { kentang }\end{array}$ & $\begin{array}{c}\text { pengembanga } \\
n \\
\text { kelembagaan } \\
\text { koperasi, } \\
\text { revitalisasi } \\
\text { pasar, } \\
\text { pembinaan } \\
\text { klaster UMKM } \\
\text { dan lelang } \\
\text { agribisnis }\end{array}$ & $\begin{array}{l}\text { pendapatan } \\
\text { masyarakat } \\
\text { lokal }\end{array}$ \\
\hline Pasuruan & $\begin{array}{c}\text { Kecamata } \\
\text { n Tutur, } \\
\text { Purwodad } \\
\text { i, Puspo, } \\
\text { Tosari, } \\
\text { kejayan } \\
\text { dan } \\
\text { Wonorejo }\end{array}$ & $\begin{array}{l}80 \text { desa, luas } \\
\text { wilayah } \\
471,56 \mathrm{Km} 2, \\
\text { jumlah } \\
\text { penduduk } \\
282.665 \text { jiwa } \\
\text { (2011) }\end{array}$ & $\begin{array}{l}\text { Kapuk randu, } \\
\text { apel, padi, } \\
\text { jagung, } \\
\text { kedelai,. tebu, } \\
\text { kenanga, } \\
\text { durian, } \\
\text { kentang, kubis, } \\
\text { paprika, sapi } \\
\text { perah. } \\
\text { Produk } \\
\text { unggulan baru, } \\
\text { yaitu bunga } \\
\text { krisan, } \\
\text { paprika, usaha } \\
\text { pembuatan } \\
\text { minuman sari } \\
\text { apel, kripik } \\
\text { kentang, } \\
\text { pengolahan } \\
\text { kopi, } \\
\text { pengembanga } \\
\text { n bigas dan } \\
\text { pakan ternak } \\
\text { alternatif }\end{array}$ & $\begin{array}{c}\text { Peningkatan } \\
\text { kualitas } \\
\text { teknologi } \\
\text { penanaman, } \\
\text { dan } \\
\text { pengembanga } \\
n \\
\text { kelembagaan } \\
\text { koperasi, } \\
\text { revitalisasi } \\
\text { pasar, } \\
\text { pembinaan } \\
\text { klaster UMKM. }\end{array}$ & $\begin{array}{l}\text { Pengembangan } \\
\text { nilai tambah } \\
\text { komoditi produk } \\
\text { unggulan } \\
\text { menjadi } \\
\text { komoditi olahan }\end{array}$ \\
\hline Sidoarjo & $\begin{array}{c}\text { Kecamata } \\
\text { n Krian }\end{array}$ & $\begin{array}{c}22 \text { desa, luas } \\
\text { kawasan } \\
32,5 \mathrm{Km} 2, \\
\text { jumlah } \\
\text { penduduk } \\
118.685 \\
(2011)\end{array}$ & $\begin{array}{c}\text { Kedelai, padi, } \\
\text { jagung, ternak } \\
\text { sapi. } \\
\text { Kedelai } \\
\text { dikembangkan } \\
\text { untuk tahu- } \\
\text { tempe, kripik, } \\
\text { snack, susu } \\
\text { kedelai, } \\
\text { nugget, dan } \\
\text { lain-lain. } \\
\text { Sementara } \\
\text { jagung } \\
\text { dikembangkan } \\
\text { untuk bahan } \\
\text { makanan dan } \\
\text { pakan ternak }\end{array}$ & $\begin{array}{c}\text { Pengembanga } \\
\text { n peran Pasar } \\
\text { Agro untuk } \\
\text { menampung } \\
\text { produk } \\
\text { unggulan } \\
\text { pertanian dari } \\
\text { kawasan } \\
\text { agropolitan } \\
\text { Bromo } \\
\text { Tengger } \\
\text { Semeru. } \\
\text { Pemberdayaa } \\
\text { n } \\
\text { kelembagaan } \\
\text { kelompok tani } \\
\text { yang } \\
\text { mendukung } \\
\text { pengembanga } \\
\text { n komoditi } \\
\text { unggulan } \\
\text { daerah }\end{array}$ & $\begin{array}{c}\text { Mendorong } \\
\text { pengembangan } \\
\text { potensi } \\
\text { komoditi lokal } \\
\text { untuk dapat } \\
\text { dikembangkan } \\
\text { menjadi produk } \\
\text { olahan dan } \\
\text { dievrsifikasi } \\
\text { produk yang } \\
\text { memberi nilai } \\
\text { tambah produk } \\
\text { tersebut }\end{array}$ \\
\hline
\end{tabular}


Kelima, salah satu bekal penting yang perlu dipahami masyarakat lokal dalam rangka upaya mereka memprediksi selera pasar adalah pengetahuan Sosiologi-Ekonomi tentang gaya hidup dan perilaku masyarakat konsumen. Pengetahuan ini penting dipahami masyarakat lokal sebagai bekal untuk mendorong mereka mengembangkan inovasi produk yang lebih kompetitif dan up to date mengikuti perkembangan selera konsumen di era masyarakat postmodern. Di sini salah satu contoh adalah munculnya produk-produk pertanian olahan yang inovatif, seperti Bakpao Telo, pia durian, kripik nangka, dan lain-lain, yang intinya adalah mengembangkan produk-produk baru yang sesuai dengan tuntutan selera konsumen.

\section{Simpulan}

Kesadaran dan komitmen Pemerintah Daerah Provinsi Jawa Timur untuk menjaga kelestarian lingkungan hidup bukan saja makin meningkat, tetapi juga makin sistematis dan implementatif. Di atas kertas telah dirumuskan kebijakan dan skenario pengembangan kawasan agropolitan Bromo Tengger Semeru. Tetapi, dalam kenyataan upaya untuk mengembangkan komoditi unggulan dan memanfaatkan kawasan tersebut ternyata bukanlah hal yang mudah. Di lapangan, ada berbagai persoalan yang timbul, bukan hanya berkaitan dengan ancaman perubahan perunutkan lahan, tetapi ditengarai juga kurangnya dukungan berbagai infrastruktur yang dibutuhkan. Kegiatan bertujuan untuk mengkaji situasi problematik yang timbul dalam upaya pengembangan kawasan agropolitan Bromo Tengger Semeru sekaligus mengkaji pengaruh kebijakan dan program pembangunan serta merumuskan rekomendasi untuk meningkatkan efektivitas kebijakan yang mendukung implementasi pembangunan yang berkelanjutan di kawasan agropolitan Bromo Tengger Semeru. Metodenya yaitu pra-lapangan, pelingkupan, baseline data, analisis, pengkajian, perumusan kebijakan program dan yang terakhir perbaikan.

Berbagai permasalahan agrobisnis telah ditemukan mulai dari produktifitas agribisnis masih belum berkembang maksimal, pelaku usaha tidak memiliki modal mandiri yang cukup, ketersediaan pasar/terminal agribisnis belum memadai, dukungan prasarana dan infrastruktur untuk menunjang kegiatan agrobisnis umumnya masih belum tersedia secara layak dan komoditi pertanian yang dihasilkan dan menjadi andalan masyarakat yang menekuni usaha agribisnis, seringkali masih rentan waktu dan belum diolah. Padahal kebijakan dan strategi pemerintah daerah dan pemerintah provinsi Jawa Timur telah di terapkan dalam upaya untuk pengebangan kawasan agropolitan Bromo Tengger Semeru. Oleh karena itu ada beberapa program utama yang harus di terapkan, Pertama, di kawasan agropolitan Bromo Tengger Semeru, perkembangan sektor pertanian di wilayah yang telah ditetapkan perlu didukung dengan perkembangan daerah penunjang, yaitu kawasan "agro eco industrial" yang berperan mendukung pengolahan produk pertanian menjadi produk olahan pertanian di tahap pasca panen yang memiliki "nilai tambah" lebih bagi petani. Kedua, memastikan agar pengembangan kawasan agropolitan Bromo Tengger Semeru tidak kontra-produktif bagi kepentingan peningkatan taraf kesejahteraan petani. Ketiga, memperhatikan ketersediaan infrastruktur penunjangnya, seperti lembaga perbankan, pasar, jaringan jalan, dan lain-lain. Keempat, mempersiapkan perkembangan modal sosial sebagai fondasi utama perubahan ke depan. Dan yang terakhir pengetahuan SosiologiEkonomi tentang gaya hidup dan perilaku masyarakat konsumen.

\section{Daftar Pustaka}

East Java Departement of Tourism, art and Culture Service (2002) Bromo Tengger Semeru National Park.

Friedman J \& Alonso W (1978) Regional Development Planning; A Reader. Cambridge: M.I.T Press.

Friedman J \& Mike D (1975) Agropolitan Development; towards a new strategi for regional development in Asia. Nagoya.

Michael L (1977) Why Poor People Stay Poor. Cambridge: Harvard University Press.

Sitorus (2010) Model kebijakan pembangunan infrastruktur berkelanjutan dalam mendukung pengembangan kawasan agropolitan. Bogor: IPB. 
Suyanto, B \& Karnaji (2005) Kemiskinan dan Kesenjangan, Ketika Pembangunan Tak Berpihak Kepada Rakyat. Surabaya: Airlangga University Press.

Suyanto \& Sulistyo (2008) Penguatan Strategi Pengembangan Kawasan Agropolitan Berbasis Peningkatan Daya Saing Produk Unggulan Agribisnis Unggulan di Kabupaten Semarang. Thesis. Semarang: Program Studi Magister Agribisnis, Program Pascasarajana Universitas Diponegoro.

Suyatno Y (2008) Penguatan Strategi Pengembangan Kawasan Agropolitan Berbasis Peningkatan Daya Saing Produk Agribisnis Unggulan Di Kabupaten Semarang. Thesis: Program Studi Magister Agribisnis Program Pascasarjana Universitas Diponegoro Semarang.

Soejono \& Abdurrahman H (2005) Metode Penelitian Suatu Pemikiran dan Penerapan. Jakarta: PT Asdi Mahasatya.

Tri US (1999) "Pengembangan Wilayah Melalui Pembukaan Kawasan Pengembangan Ekonomi Terpadu". Dalam Tiga Pilar Pengembangan Wilayah: Sumberdaya Alam, Sumberdaya Manusia, Teknologi. BPPT, Jakarta. 